\title{
Antioxidant activity, cito- and phototoxicity of pomegranate (Punica granatum L.) seed pulp extract
}

\author{
Atividade antioxidante, cito- e fototoxicidade do extrato das sementes de romã (Punica granatum L.)
}

Carla Aparecida PEDRIALI ${ }^{1 \star}$, Adjaci Uchoa FERNANDES², Patricia Araujo dos SANTOS², Moisés Melquíades da SILVA², Divinomar SEVERINO², Mauricio Baptista da SILVA²

\section{Resumo}

Neste trabalho, foi realizada a extração de sementes inteiras de romã (Punica granatum L. - Punicaceae) com cachaça durante 80 horas no escuro. A curva de dessorção do extrato apresentou um tempo ótimo de extração das sementes de aproximadamente 24 horas. $\mathrm{O}$ extrato obtido foi dividido em duas amostras, uma delas foi mantida protegida da luz ambiente (extrato 1) e a outra não (extrato 2). As amostras foram caracterizadas por espectroscopia Ultravioleta-Visível, quantificação de polifenóis totais pelo método de Folin-Ciocalteu e pela atividade antioxidante utilizando o ensaio de inibição do radical DPPH. A exposição do extrato à luz ambiente, o fez perder 9,8\% do seu teor de polifenóis totais (de 0,353 para 0,322 g. $\mathrm{L}^{-1}$ ). Por outro lado, a atividade antioxidante caiu a 20,7\% (de 3,4 para 0,7 mM de trolox). A adição de até $3 \%$ do extrato 1 de sementes de romã não afetou significativamente a viabilidade de células epiteliais in vitro. As mesmas células tratadas com o extrato 1 e irradiadas com um simulador solar não apresentaram fototoxicidade na mesma faixa de concentração. Assim, foi possível concluir que os componentes das sementes de Punica granatum L. (romã) podem ser extraídos por contato direto com cachaça por um período de 80 horas no escuro, conferindo-lhe uma boa coloração e também propriedades organolépticas agradáveis. Tal extrato não apresenta citotoxicidade e nem fototoxicidade, embora o extrato tenha se mostrado fotoinstável.

Palavras-chave: romã; cinética de extração; cachaça; antioxidante.

\begin{abstract}
In the present work, a hydroethanolic extract was prepared from the entire seeds of pomegranate [Punica granatum L. (Punicaceae)] with Cachaça, a distilled Brazilian alcoholic beverage, protected from light for an 80-hour period. The desorption curve of the seeds, presented an optimal time extraction of approximately 24 hours. The extract was divided into two samples: protected from light, (Extract 1), or not, (Extract 2). The extracts were characterized by UV-Visible absorption spectroscopy, quantification of total phenolics by the Folin-Ciocalteu method, and the antioxidant activity was determined by the DPPH quenching method. Extract 2 presented $9.8 \%$ less total polyphenols than Extract 1 . The pomegranate seeds extract lost $79 \%$ of its antioxidant activity during light exposure. Extract 1 up to $3 \%$ (w/v) showed neither cyto nor phototoxicity in the Hela cells. In conclusion, Punica granatum L. seeds contain a significant total polyphenol and TEAC amount and they can be used in simple extractive process, by direct contact with Cachaça in up to 80 hours in the darkness, which gives it good coloration, taste, and smell. This extract showed neither cytotoxicity nor post-irradiation phototoxicity with solar simulator even though the extract proved photoinstable.

Keywords: pomegranate; extraction kinetics; cachaça; antioxidant.
\end{abstract}

\section{Introduction}

Pomegranate is a native fruit from Iran to the Himalayas in Northern India and it has been both cultivated and naturalized throughout the whole Mediterranean region since ancient times. Pomegranates prefer a semi-arid mild-temperate to subtropical climate and are naturally adapted to regions that have cool winters and hot summers, but they can be found from South to North America. A humid climate adversely affects the formation of this fruit. The present scientific name, Punica granatum L. (Punicaceae), was derived from the name pomuni granatum (seeded apple) given to the fruit in the Middle Ages (ADSULE; PATIL, 1995).

Hydroalcoholic extract of the entire fruit of Punica granatum is popularly used in the treatment of respiratory illnesses in
Cuba, Brazil, and other countries (VIDAL et al., 2003; LANSKY; NEWMAN, 2007). Some substances have been identified in these kinds of extracts, such as reducing sugars, mucilage, glycosides, phenols, tannins, flavonoids, anthocyanines pigments, and alkaloids (MERTENS-TALCOTT et al., 2006). Sas seed The strong antioxidant activities of the hydroethanolic extract can also be found in fermented beverages as well as in seed oils (ADSULE; PATIL, 1995; SCHUBERT; LANSKY; NEEMAN, 1999) and in fruit juices (ZAID et al., 2007). Such activity is due to the mixture of the substances mentioned above and mainly due to the presence of hydrolyzed tannins. The latter are converted during metabolism into ellagic acids, also known as ellagitannins (punicalagin is a major ellagitannin).

Recebido para publicação em 12/11/2008

Aceito para publicação em 25/9/2009 (003951)

Departamento de Fármaco e Medicamentos, Faculdade de Ciências Farmacêuticas, Universidade de São Paulo - USP, CEP 05508-900, São Paulo - SP, Brasil,

E-mail: capedriali@hotmail.com

2 Departamento de Bioquímica, Universidade de São Paulo - USP, CEP 05508-900, São Paulo - SP, Brasil

${ }^{*}$ A quem a correspondência deve ser enviada 
The mechanisms of uptake in vivo are not properlyclearly established, but there isare data available in the literature indicating that glicosilated poliphenols are well internalized after ingestion (HOLLMAN et al., 1996; CHEN et al., 2007).

Preliminary laboratory studies demonstrated that these extracts and pomegranate juice have been found to effectively reduce heart disease risk factors and atherosclerosis including LDL oxidation and macrophage oxidative status (AVIRAM et al., 2000). Punicalagins have been identified as the primary components responsible for the reduction of oxidative stress, due to their potent free-radical scavenging ability, which led to these risk factors (AVIRAM et al., 2000; SINGH; CHIDAMBARAMURTHY; JAYAPRAKASHA, 2002). Pomegranate has proved to reduce systolic blood pressure by inhibiting serum Angiotensin-Converting Enzyme (ACE) (AVIRAM; DORNFELD, 2001). Other research indicates that pomegranate juice may be effective against prostate cancer and osteoarthritis (SEERAM et al., 2007). Previous findings on the anti-influenza activity of Punica granatum extracts have given support to ethnopharmacological applications (ZHANG et al., 1995; NEURATH et al., 2004). Also, some studies have been carried out in order to investigate the antibacterial effects of extracts against dental plaque (MENEZES; CORDEIRO; VIANA, 2006). Some investigations focus on the toxicity evaluation of whole fruit hydroalcoholic extract of Punica granatum L. used in Cuban traditional medicine for the treatment of respiratory diseases; and it was found that toxic effects of Punica granatum fruit extract occurred at higher doses than those that are effective in chick embryo models (VIDAL et al., 2003).

Phenolics compounds constitute one of the major groups of molecules acting as primary antioxidants or free radical terminators; therefore the total amount of these compounds was determined in the selected pomegranate extracts. Flavonoids, one of the most diverse and widespread group of phytochemical components, are probably the most important natural phenolics. These compounds possess a broad spectrum of chemical and biological activities, including radical scavenging properties. Such properties are especially distinct for flavonols, such as punicalagins that are found in pomegranate seed pulp (SOMERS, 1971). Folin-Ciocalteau's method allows the estimation of all flavonoids, anthocyanins, and nonflavonoid phenolic compounds present in the samples through the reduction of $\mathrm{Mo}^{\mathrm{VI}}$ to $\mathrm{Mo}^{\mathrm{V}}$ and $\mathrm{W}^{\mathrm{VI}}$ to $\mathrm{W}^{\mathrm{V}}$ by antioxidant compounds with the formation of a blue $\mathrm{W}^{\mathrm{V}} / \mathrm{Mo}^{\mathrm{V}}$ complex with maximum absorption at $765 \mathrm{~nm}$ (SINGLETON; ROSSI, 1965; SINGLETON; ORTHOFER; LAMUELA-ROVENTOS, 1999).

DPPH radicals are widely used to investigate the scavenging activities of several natural compounds. When DPPH radical is scavenged, the color of the reaction mixture changes from purple to yellow with a decrease in absorbance decreasing at $515-517 \mathrm{~nm}$ (BRAND-WILLIANS; CUVELICI; BERSET, 1995; SANCHEZMORENO et al., 1998). This method is simple, fast, sensitive, as well as beingand it is a stable radical at room temperature doesn't that does not require expensive reagents or sophisticated instrumentation. Antiradicalar capacity is normally expressed in Trolox equivalent (NENADIS; LAZARIDOU; TSIMIDOU, 2007, HUANG; OU; PRIOR, 2005).
As there is little data in the literature on the use of Punica granatum L. extracts in Cachaça (the most popular distilled alcoholic beverage in Brazil), our research group considered the production of a pleasant tasting drink, which has an important therapeutic value. For this reason, the purpose of this work was to optimize the extraction process and characterize the extracted components through the evaluation of citotoxicity, phototoxicity, total polyphenols, antioxidant activity, and photo-stability.

\section{Materials and methods}

\subsection{Materials}

2,2-diphenyl-1-picryhydrazyl radical (DPPH), 6-hydroxy2,5,7,8-tetramethylchroman-2-carboxilic acid (Trolox), gallic acid, and 3-(4,5-Dimethyl-2-thiazolyl)-2,5-diphenyl-2Htetrazolium bromide (MTT) were obtained from Sigma-Aldrich Chemical, USA. All other chemicals and solvents were reagent grade.

\subsection{Extraction and testing sample preparation}

Ripe fruits were harvested in the winter (July 2007) from a collection of plants in the northern region of the city of São Paulo - Brazil. The fruits without splits were kept without light for five days at an average temperature between 20 to $25^{\circ} \mathrm{C}$. The extraction was performed by shaking flasks with $183.7 \mathrm{~g}$ of entire seeds of Punica granatum L. and $500 \mathrm{~mL}$ of commercial Brazilian Cachaça (from Carote, Missiato Ind. Com. Ltda, Santa Rita do Passa Quatro - SP, Brazil, 39\% alcohol graduation) for 80 hours in darkness. The extracts were filtered, concentrated in a rotary evaporator apparatus at approximately $40{ }^{\circ} \mathrm{C}$, and characterized by UV-Visible spectroscopy. The extract samples were storedin the appropriately (ODDO, 1920), as follows:

Hydroalcoholic extract from the entire seeds of Punica granatum L. (Punicaceae)

- Extract 1 (07/07/2007, kept in a package and protected from light);

- Extract $2(07 / 07 / 2007$, kept in a package and exposed to light).

\subsection{Estimation of total phenolic content}

The total phenolic content of Punica granatum seeds extracts was quantified using the Folin-Ciocalteu (SINGLETON; ROSSI, 1965; SINGLETON; ORTHOFER; LAMUELA-ROVENTOS, 1999; SINGH; CHIDAMBARA-MURTHY; JAYAPRAKASHA, 2002) method. The reaction mixture contained $25 \mu \mathrm{L}$ of seeds extracts $\left(266\right.$ g. $\left.\mathrm{L}^{-1}\right), 500 \mu \mathrm{L}$ from the Folin-Ciocalteu reagent, and $1.5 \mathrm{~mL}$ of $20 \%$ sodium carbonate. The final volume made up to $10 \mathrm{~mL}$ with pure water. After 2 hours of reaction at $20^{\circ} \mathrm{C}$, the absorbances were read at $765 \mathrm{~nm}$ using a UV-VIS recording spectrophotometer (TCC-240A Shimadzu Corporation). The quantification was done with respect to the standard curve of gallic acid (0.5 to $\left.5 \mathrm{mg} \cdot \mathrm{L}^{-1}\right)$, and the results were expressed as Gallic Acid Equivalents (GAE). All determinations were performed in quadruplicate $(n=4)$. 


\subsection{Free radical-scavenging ability by the use of a stable DPPH radical}

The free radical scavenging properties of Punica granatum seeds extracts were evaluated by spectrophotometric method using the stable 2,2-diphenyl-1-picryhydrazyl radical (DPPH.) (BRAND-WILLIANS; CUVELICI; BERSET, 1995; SANCHEZMORENO et al., 1998), adapted to a 96 well-plate. $60 \mu \mathrm{L}$ of a $0.4 \mathrm{mM}$ DPPH. ethanol stock solution was added to $30 \mu \mathrm{L}$ of sample extracts of different concentrations, and the final volume made up to $300 \mu \mathrm{L}$ with ethanol. DPPH. solution $(80 \mu \mathrm{M})$ was used as a negative control. The reaction was carried out at $18{ }^{\circ} \mathrm{C}$ for 20 minutes and the absorbance at $515 \mathrm{~nm}$ was measured using a multiwell plate reader (Sunrise ${ }^{\mathrm{TM}}$ Remote Control, Tecan) interfaced with the Magellan software. The radical DPPH. scavenging capacity was estimated from the difference in absorbance with or without antioxidants and expressed as percent DPPH. remaining. The Trolox (water soluble homologue of vitamin E) was used as standard (3.5 to $50 \mu \mathrm{M})$. The Trolox Equivalent Antioxidant Capacity (TEAC) values were calculated by polynomial regression of plots, in which the abscissa represented the concentration of tested plant extracts and the ordinate, and the average percent of remaining $\mathrm{DPPH} \cdot$ at steady state from four separate tests $(n=4)$.

\subsection{Citotoxicity and photocitotoxicity evaluation}

HeLa cells (human cervical carcinoma cell line) were cultured in Dulbecco's Modified Eagle's Medium (DMEM) supplemented with $10 \%$ fetal bovine serum and $0.5 \%$ streptomycin and penicillin at $37^{\circ} \mathrm{C}$ and $5 \% \mathrm{CO}_{2}$ (MOSMANN, 1983). 6-well-plates were prepared with $10^{5}$ cells/well. After 18 hours, the cells were incubated with DMEM + Punica granatum seeds extracts (1, 2 and 3\%; w/v) for 3 hours. Next, DMEM + extracts were changed by a MTT solution (1.5 mg. $\mathrm{mL}^{-1}$ in PBS) and incubated for 2 hours. MTT is a compound that forms a complex with mitochondrial enzymes in living cells, in which it is transformed into formazan. The MTT solution was changed by dimethylsulfoxide (DMSO) to dissolve the formazan christals formed. After one hour, the absorptions at $550 \mathrm{~nm}$ were measured. The experiments were performed in triplicate. DMEM + PBS were used as a negative blank and Antimicin A as a positive control. The irradiation was performed with a solar simulator, which emits radiation UVA, UVB, and visible light.

\section{Results and discussion}

The desorption curves of the seeds were obtained by UVVisible spectroscopy (Figure 1a), and two peaks were followed (Figure 1b). The first peak (367 $\mathrm{nm}$ ) refers to polyphenols and the second one $(525 \mathrm{~nm})$ refers to the anthocyanins presents in the extract. The desorption curves show an optimal time extraction for the compounds from seed extract of approximately 24 hours.

The results indicate that cells do not undergo significant change in their viabilities in relation to the control group, following exposure to extract 1 of up to $3.0 \%$ for 3 hours (Figure 2a). Under irradiation with a solar simulator, there was a reduction in cell viability with the increase of concentration of extract to 2.0 and $3.0 \%$ (Figure $2 \mathrm{~b}$ ). The extract presented neither citotoxicity nor phototoxicity at the tested concentrations.

Table 1 reports the antiradical capacity and the amount of total polyphenols in each pomegranate seeds extract: Extract 1 (light protected) and Extract 2 (light unprotected). Extract 1 exhibited a higher amount of total polyphenols than that found in Extract 2. The difference between them represents a reduction of $9.8 \%$ in the amount of total polyphenols in Extract 2 during the 3 months of storage. Aside from this, there was an important reduction of $79 \%$ in the free radical scavenging capacity between the extracts, as shown in Figure 3.

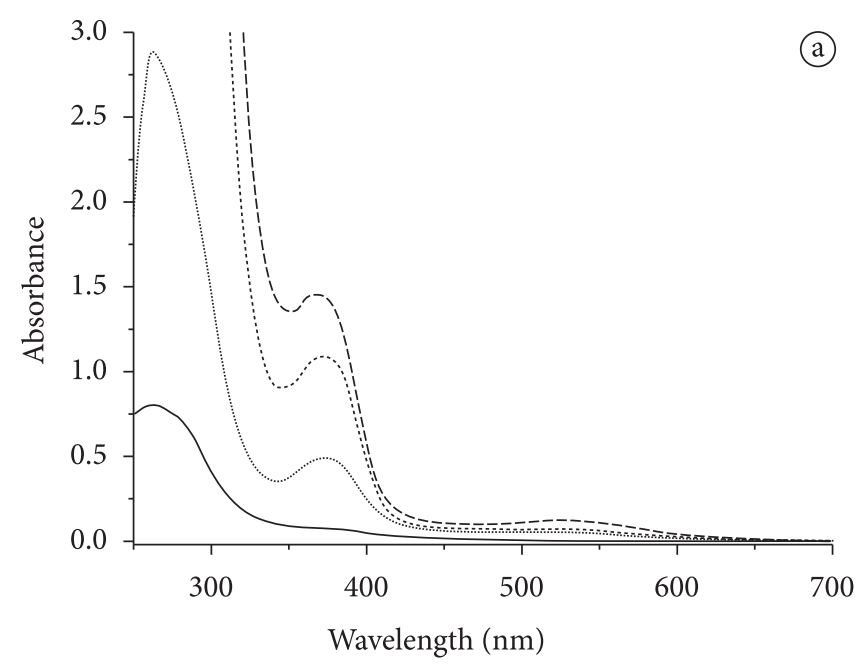

— T 0 hour …… T 2 hours ….. T 24 hours --- T 81 hours

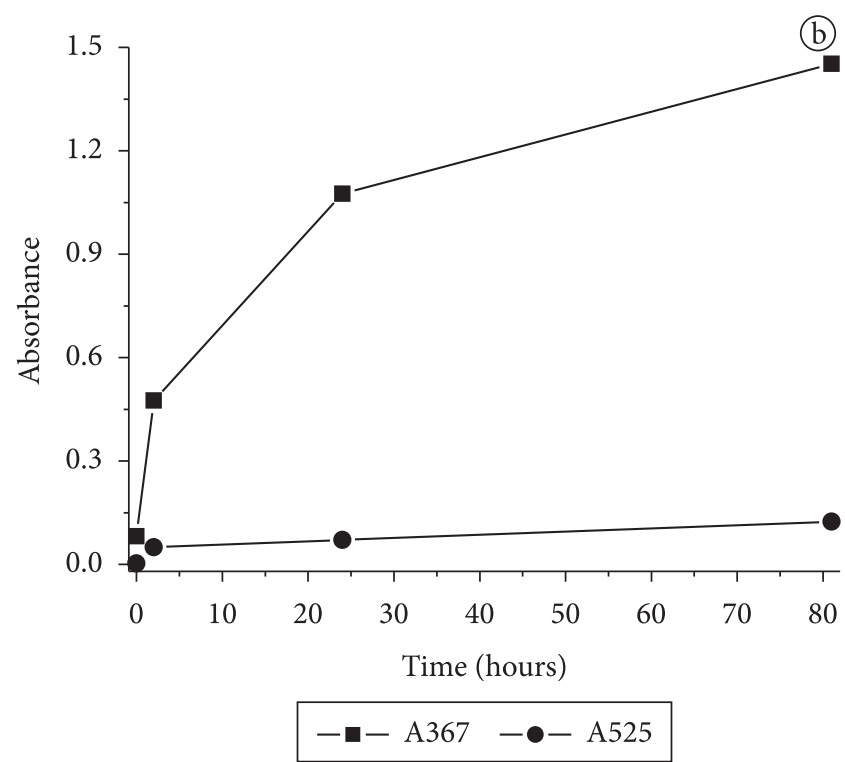

Figure 1. Desorption curve of Punica granatum seeds glicohydroethanolic extract: a) Absorption spectra at different time of extraction; b) Absorption intensity at 367 and $525 \mathrm{~nm}$ in function of extraction time. 

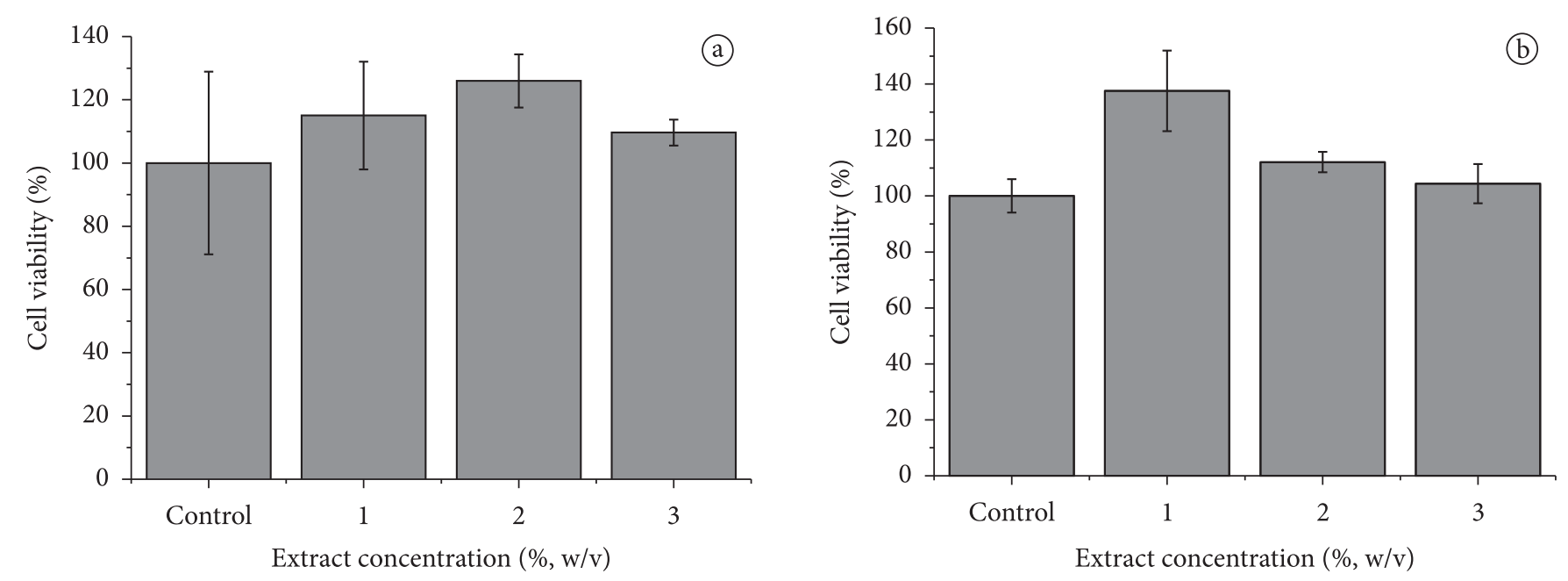

Figure 2. a) Cito; and b) phototoxicity of Hela cells were treated with glicohydroethanolic and were irradiated with a solar simulator (UVA + $\mathrm{UVB}+\mathrm{Vis})$.
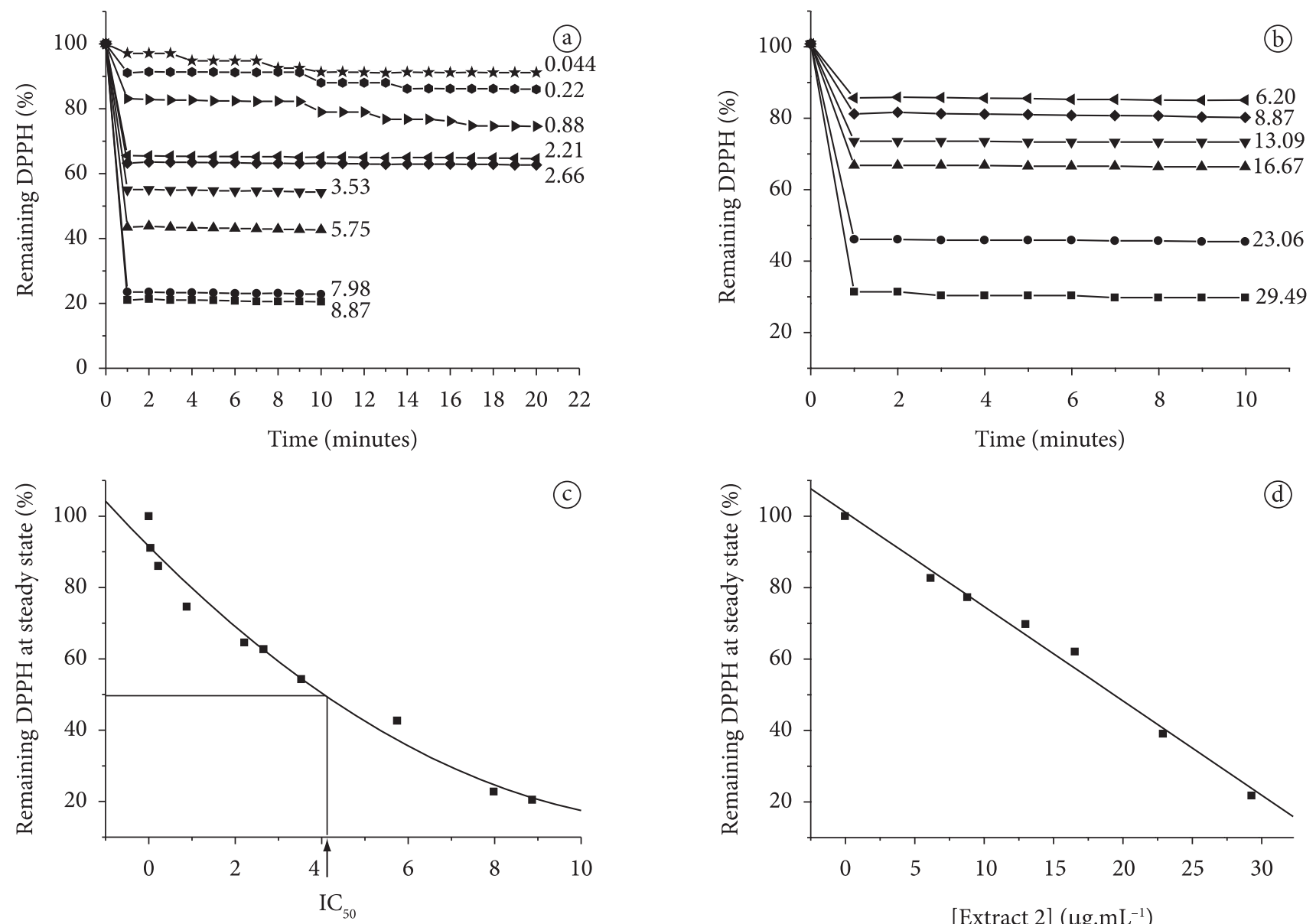

[Extract 1] $\left(\mu \mathrm{g} \cdot \mathrm{mL}^{-1}\right)$

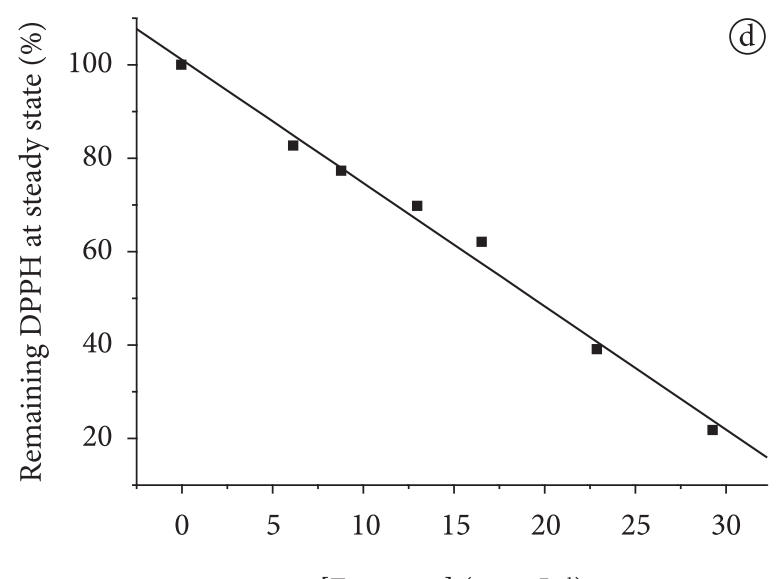

[Extract 2] $\left(\mu \mathrm{g} \cdot \mathrm{mL}^{-1}\right)$

Figure 3. Reaction kinetics of pomegranate extracts with DPPH radical. The DPPH radical concentration was $80 \mu \mathrm{M}$ in all reaction mixtures. All tests were conducted in quadruplicate, and the means are used. a) Final extract 1 concentrations: 0.044, 0.22, 0.88, 2.21, 2.66, 3.53, 5.75, 7.98, and $8.87 \mu \mathrm{g} . \mathrm{mL}^{-1}$ in the reaction mixtures; b) Final extract 2 concentrations: 6.20, 8.87, 13.09, 16.67, 23.06, and 29.49 $\mu$ g.mL $\mathrm{mL}^{-1}$ in the reaction mixtures; c) and d) Disappearance of DPPH radical as a function of the concentration of extracts: definition of IC $_{50}$ (amount of antioxidant necessary to decrease the initial DPPH radical concentration by $50 \%)$. 
Table 1. Total phenolic content and free radical-scavenging capacity in the 2 samples of pomegranate seeds extracts.

\begin{tabular}{ccc}
\hline $\begin{array}{c}\text { Samples of } \\
\text { pomegranate extracts }\end{array}$ & $\begin{array}{c}\text { Total phenolic content } \\
\text { a } \\
\text { g.L } \mathrm{L}^{-1}(\mathrm{mM})\end{array}$ & $\begin{array}{c}\text { TEAC value for } \mathrm{DPPH}^{\mathrm{b}} \\
\text { MM }\end{array}$ \\
\hline Extract 1 & $0.353 \pm 0.002$ & $3.097 \pm 0.021$ \\
& $(1.96 \pm 0.01)$ & \\
Extract 2 & $0.322 \pm 0.002$ & $0.696 \pm 0.009$ \\
& $(1.79 \pm 0.01)$ & \\
\hline
\end{tabular}

${ }^{\text {aTotal phenolic content was expressed in grams of gallic acid equivalent per } 1 \mathrm{~L} \text { of }}$ pomegranate extract $\left(\mathrm{GAE} . \mathrm{L}^{-1}\right)$. Molar concentration is between parentheses to compare with TEAC; ${ }^{b}$ Total Equivalent Antioxidant Capacities (TEAC) were expressed as $\mathrm{mM}$ of Trolox of pomegranate extract. All values are the means of four measurements $(n=4)$.

Our results reinforce the importance of light protection tofor the extracts sinceas light exposure somewhat reduced the total polyphenol contentsomewhat, while causing, however, an important reduction in the antioxidant capacity.

\section{Conclusions}

Punica granatum seed pulp extract presents neither citotoxicity nor phototoxicity, and it can be used like a natural dye in alcoholic beverages. A simple extraction by direct contact of the seeds with the beverage for 24 hours is enough to confer good coloration, taste, and smell to Cachaça. However, the data of total polyphenols content and especially in the antiradical capacity, have shown that the seed extract is photoinstable and, therefore, the type of bottle (light or non-light) used for the storingage of this extract, interferes in its biological and functional activities.

\section{Abbreviations used}

DPPH', 2,2-diphenyl-1-picryhydrazyl radical; Trolox (water soluble homologue of vitamin E), 6-hydroxy2,5,7,8-tetramethylchroman-2-carboxilic acid; MTT, 3-(4,5-dimethylthiazol-2-yl)-2,5-diphenyltetrazolium bromide; DMEM, Dulbecco's Modified Eagle's Medium; PBS, Phosphate Buffered Saline; DMSO, dimethylsulfoxide.

\section{Acknowledgment}

We would like to thank Dr. José Roberto Machado Cunha da Silva for allowing the use of the multiwell plate reader from the Department of Histology and Embryology, Institute of Biomedical Sciences (ICB-USP/Brazil). This work was supported by CAPES. D.S. thanks Farma Service BioExtract Ltda.

\section{References}

ADSUlE, R. N.; PATIL, N. B. Pomegranate. In: SALUNKHE, D. K.; KADAM, S. S. (Eds.) Handbook of Fruit Science and Technology. Dekker: New York, 1995. p. 455-464.

AVIRAM, M. et al. Pomegranate juice consumption reduces oxidative stress, atherogenic modification to LDL and platelet aggregation: studies in human and in atherosclerotic apolipoprotein deficient mice. American Journal of Clinical Nutrition, v. 71, p. 1062-1076, 2000.

AVIRAM, M.; DORNFELD, L. Pomegranate juice consumption inhibits serum angiotensin converting enzyme activity and reduces systolic blood pressure. Atherosclerosis, v. 158, n. 1, p. 195-198, 2001.

BRAND-WILLIANS, W.; CUVELICI, M. E.; BERSET, C. Use of a free radical method to evaluate antioxidant activity. LebenswittelWissenschaft und Technologie, v. 28, p. 25-30, 1995.
CHEN, T. et al. Absorption and excretion Luteolin and Apigenin in rats after oral administration of Chrysanthemum morifolium extract. Journal Agricultural and Food Chemistry, v. 55, p. 273 277, 2007.

HOLLMAN, P. C. H. et al. Absorption and disposition kinetics of the dietary antioxidant Quercetin in man. Free Radical Biology \& Medicine, v. 21, n. 5, p. 703-707, 1996.

HUANG, D.; OU, B.; PRIOR, R. L. The chemistry behind antioxidant capacity assays. Journal of Agricultural and Food Chemistry, v. 53, p. 1841-1856, 2005.

LANSKY, E. P.; NEWMAN, R. A. Punica granatum (pomegranate) and its potential for prevention and treatment of inflamation and cancer. Journal of Ethnopharmacology, v. 109, p. 177-206, 2007.

MENEZES, S. M. S.; CORDEIRO, L. N.; VIANA, G. S. B. Punica granatum (pomegranate) extract is active against dental plaque. Journal of herbal pharmacotherapy, v. 6, n. 2, p. 79-92, 2006.

MERTENS-TALCOTT, S. U. et al. Absorption, metabolism, and antioxidant effects of pomegranate (Punica granatum $\mathrm{L}$.) polyphenols after ingestion of a standardized extract in healthy human volunteers. Journal of Agricultural and Food Chemistry, v. 54, n. 23, p. 8956-8961, 2006.

MOSMANN, T. Rapid colorimetric assay for cellular growth and survival: application to proliferation and cytotoxicity assays. Journal of Immunological Methods, v. 65, p. 55-63, 1983.

NENADIS, N.; LAZARIDOU, O.; TSIMIDOU, M. Z. Use of reference compounds in antioxidant activity assessment. Journal of Agricultural and Food Chemistry, v. 55, p. 5452-5460, 2007.

NEURATH, A. R. et al. Punica granatum (Pomegranate) juice provides an HIV-1 entry inhibitor and candidate topical microbicide. BMC Infectious Diseases, v. 4, p. 41, 2004.

ODDO, B. Extracts prepared according to the official Italian pharmacopeia II. Giornale di Chimica Industriale ed Applicata, v. 2, p. 381-387, 1920.

SANCHEZ-MORENO, W.; LARRAURI, J. A.; SAURA-CALIXTO, F. A procedure to measure the antiradical efficiency of polyphenols, Journal of the Science of Food and Agriculture, v. 76, p. 270-276, 1998.

SCHUBERT, S. Y.; LANSKY, E. P.; NEEMAN, I. Antioxidant and eicosanoid enzyme inhibition properties of pomegranate seed oil and fermented juice flavonoids. Journal of Ethnopharmacology, v. 66, p. 11-17, 1999.

SEERAM, N. P. Pomegranate ellagitannin-derived metabolites inhibit prostate cancer growth and localize to the mouse prostate gland. Journal of Agricultural and Food Chemistry, v. 55, p. 7732-7737, 2007.

SINGH, R. P.; CHIDAMBARA-MURTHY, K. N.; JAYAPRAKASHA, G. K. Studies on antioxidant activity of pomegranate (Punica granatum) peel and seed extracts using in vitro models. Journal of Agricultural and Food Chemistry, v. 50, p. 81-86, 2002.

SINGLETON, V. L.; ORTHOFER, R.; LAMUELA-ROVENTOS, R. M. Analysis of total phenols and other oxidation substrates and antioxidants by means of folin-ciocalteu reagent. Methods in Enzymology, v. 299, p. 152-178, 1999.

SINGLETON, V. L.; ROSSI, J. A. J. R. Colorimetry of total phenolics with phosphomolybdicphosphotungstic acid reagent. American Journal of Enology and Viticulture, v. 16, p. 144-158, 1965.

SOMERS, T. C. The polymeric nature of wine pigments. Phytochemistry, v. 10 , p. $2175-2184,1971$.

VIDAL, A. et al. Studies on the toxicity of Punica granatum L. (Punicaceae ) whole fruit extracts. Journal of ethnopharmacology, v. 89, n. 2-3, p. 295-300, 2003.

ZAID, M. A. et al. Inhibition of UVA-mediated oxidative stress and markers of photoaging in immortalized HaCaT keratinocytes by pomegranate polyphenol extract POMx. Photochemistry and Photobiology, v. 83, p. 882-888, 2007.

ZHANG, J. et al. Antiviral activity of tannin from the pericarp of Punica granatum L. against genital Herpes virus in vitro. Zhongguo Zhong Yao Za Zhi = Zhongguo Zhongyao Zazhi = China Journal Of Chinese Materia Medica, v. 20, n. 9, p. 556-576, 1995. 